\title{
Preparation of the discharge of relatives of children using antibiotics: contributions of nursing ${ }^{a}$
}

Preparo de alta de familiares de crianças em uso de antibiótico: contribuições da enfermagem Preparación de los parientes para el alta de niños medicados con antibióticos: contribuciones de la enfermería

Liliane Faria da Silva ${ }^{1}$ (i)

Emília Gallindo Cursino ${ }^{1}$ (1D)

Fernanda Garcia Bezerra Góes ${ }^{2}$ (D) Amanda Danielle Resende Silva e Sousa ${ }^{1}$ (D) Juliana Rezende Montenegro Medeiros de Moraes $^{3}$ (i)

1. Universidade Federal Fluminense, Escola de Enfermagem Aurora de Afonso Costa. Niterói, RJ, Brasil.

2. Universidade Federal Fluminense, Departamento de Enfermagem. Rio das Ostras, RJ, Brasil.

3. Universidade Federal do Rio de Janeiro, Escola de Enfermagem Anna Nery. Rio de Janeiro, RJ, Brasil.
Corresponding author:

Liliane Faria da Silva.

E-mail: lili.05@hotmail.com

Submitted on $04 / 09 / 2019$.

Accepted on 07/26/2019.

DOI: 10.1590/2177-9465-EAN-2019-0108

\begin{abstract}
Objective: To describe the discharge preparation for relatives of hospitalized children for continuing antibiotic therapy at home, from the nurse perspective. Method: A descriptive and qualitative research, performed in the ward of a pediatric hospital in Rio de Janeiro. It was attended by fifteen nurses through semi-structured interviews, between April and May 2018, and data was submitted to Thematic Analysis. Results: The following thematic units emerged: Preparing the relatives for the discharge as a punctual moment; Professionals involved in the preparation of the discharge for relatives; Educational strategies in preparing the relatives for the discharge; and Communication among professionals in preparing the relatives for the discharge. Conclusion and implications for practice: There is a need to systematize the discharge process of the child that leaves the hospital to finish their therapeutic scheme with antibiotics at home, thereby avoiding inappropriate use and therapeutic errors.
\end{abstract}

Keywords: Child Health; Patient Discharge; Caregivers; Antibiotic; Patient Safety.

\section{Resumo}

Objetivo: Descrever o preparo de alta de familiares de crianças hospitalizadas para a continuidade da antibioticoterapia no domicílio, na perspectiva dos profissionais de enfermagem. Método: Pesquisa qualitativa descritiva, realizada na enfermaria de um hospital pediátrico do Rio de Janeiro. Quinze profissionais de enfermagem participaram da entrevista semiestruturada entre abril e maio de 2018, e os dados foram submetidos à Análise Temática. Resultados: Emergiram as seguintes unidades temáticas: Preparo de alta dos familiares como um momento pontual; Profissionais envolvidos no preparo de alta dos familiares Estratégias educativas no preparo de alta dos familiares; e Comunicação entre profissionais no preparo de alta dos familiares. Conclusão e implicações para a prática: É preciso sistematização do processo de alta da criança que deixa o hospital para completar esquema terapêutico de antibiótico no domicílio, para assim evitar uso inadequado e falhas na terapêutica.

Palavras-chave: Saúde da Criança; Alta do Paciente; Cuidadores; Antibiótico; Segurança do Paciente.

\section{REsumen}

Objetivo: Describir la preparación de los parientes para el alta de niños hospitalizados a fin de proseguir el tratamiento con antibióticos a domicilio, desde la perspectiva de los enfermeros. Método: Investigación cualitativa descriptiva, realizada en la enfermería de un hospital pediátrico en Río de Janeiro. Participaron del estudio quince enfermeros mediante entrevistas semiestructuradas, entre abril y mayo de 2018, y los datos se sometieron al Análisis Temático. Resultados: Emergieron las siguientes unidades temáticas: Preparación de los parientes para el alta como un momento puntual; Profesionales involucrados en la preparación de los parientes para el alta; Estrategias educativas en la preparación de los parientes para el alta; y Comunicación entre profesionales en la preparación de los parientes para el alta. Conclusión e implicaciones para la práctica: Es necesario sistematizar el proceso de alta del niño que deja el hospital para concluir el esquema terapéutico de antibióticos a domicilio, con miras a evitar el uso inadecuado y fallas en la terapia.

Palabras clave: Salud del niño; Alta del paciente; Cuidadores; Antibiótico; Seguridad del paciente. 


\section{INTRODUCTION}

An antibiotic is the drug capable of fighting infections caused by bacteria. It may have a bacteriostatic action, which inhibits bacterial growth, or a bactericide action that promotes bacterial death. Like any other drug, it may cause reactions such as hypersensitivity, toxicity and superinfection. The indiscriminate use of antibiotics has given rise to resistant bacteria, which are no longer fought with antibiotics and doses to which they were previously sensitive. ${ }^{1}$

In pediatrics, antibiotics are among the most widely used classes of drugs for treating respiratory and urinary tract, skin and soft tissue infections. ${ }^{2}$ It is noteworthy that the metabolism related to the growth and development of children is differentiated from adults, altering the pharmacological action of the antibiotic, which requires rational use and careful attention in the storage, dispensing, prescription and administration to prevent further damages. $^{3}$

A study addressing the safety strategies in drug administration in children found that intravenous use was the most commonly used for this public in the hospital setting. ${ }^{4}$ However, many children with infection begin parenteral antibiotic therapy in the hospital and complete the oral home therapy regimen.

Ending treatment at home favors early hospital discharge, which in turn reduces the length of stay and decreases the negative effects separating the child and family from the social environment. However, this imposes on relatives the responsibility for continuing treatment until the complete recovery of the child with autonomy, quality and safety. ${ }^{5}$

For children who, after the discharge from hospital, will continue to use medication at home, such as antibiotics, guidelines with families regarding the action of the drug in the body, possible adverse reactions and complications, storage, dosage, efficacy and interactions with other medications, especially adherence to dose schedules, especially in cases of antibiotic therapy, are important. ${ }^{5}$

Aspects involving patient safety have been a matter of concern on national and international levels, especially in pediatrics, given the vulnerability of this population group. A review study that sought evidence for the safe care of hospitalized children showed that in pediatric nursing safe care is based on several interfaces, such as quality of the records, the use of checklists in the procedures, improvements in the drug giving process and in professional training, and parental involvement in care. ${ }^{6,7}$

Thinking about the child in transition from hospital care to home care, the occurrence of errors or failures in the therapeutic process at home, related to drug use, may result in ambulatory or emergency care and hospital readmission. In this sense, the complexity of post-discharge drug use, with a focus on patient safety, ${ }^{8}$ stresses the need for the nursing staff to be involved in preparing the relatives for the discharge of children using antibiotics at home, especially the nurse, considering their social role as a health educator.
Although the number of studies addressing the safety of pediatric patients and the need for family involvement in the therapeutic process is increasing, researches that specifically address the preparation of families regarding home care with antibiotic therapy are incipient. ${ }^{4,6-8}$

Given the above, the following guiding question was formulated for the study: How does discharge preparation for relatives of hospitalized children happen for continuing antibiotic use at home? From this perspective, the objective was to describe the discharge preparation for relatives of hospitalized children for continuing antibiotic therapy at home, from the perspective of nursing professionals.

\section{METHOD}

This study is configured as a descriptive research with a qualitative approach, ${ }^{9}$ performed in the ward, inpatient sector, of a pediatric hospital, belonging to the Metropolitan Region II of the state of Rio de Janeiro, Brazil.

The inpatient sector consists of six wards with more than 2 beds each and three quarters for contact precaution, totaling 24 beds serving children and adolescents from zero to 18 years old. Nursing professionals work with a regime of 12 hours for 60 hours of rest, being four technicians and one nurse on duty and one diarist nurse. The sector has three doctors who make the daily assessment of children, usually in the morning shift. After this time, medical assistance is given by contact with the on-duty doctor; it is added that there is no full-time pharmacist in the study scenario sector, as this one remains in the pharmacy. In addition, the nursing staff acts integrally in the unit, 24 hours a day, in the clinical care of hospitalized children and their families, from admission to discharge.

In this scenario, it is common for children with different pathologies to be admitted on antibiotic therapy, many of whom experience the transition from hospital to home with the need to complete the post-discharge drug regimen, which made this scenario appropriate for analyzing how the preparation of relatives for the discharge happened on the thematic scope, to the extent that this process was not known.

It is noteworthy that the selection by the nursing team occurred considering that they remain longer in the unit compared to other health professionals, thus favoring a thorough description of this process in the unit to achieve the study objective.

Thus, the inclusion criteria were the following: nursing professionals with 06 or more months of experience in the sector. The following were excluded: nursing professionals being offduty because of vacations, premium leave, maternity leave, sick leave,or in nuptials. It is noteworthy that they were picked up in the sector at random, at which time when the researcher made the invitation to participate in the research. All the invitees agreed to participate and the number of professionals was delimited by the theoretical saturation of data, when there were no new elements in the statements. ${ }^{10}$ 
Data was collected through semi-structured interviews conducted on April and May, 2018. A script with the following questions was used: How to prepare relatives of the child who will be using antibiotics at home after hospital discharge? How do you think should be the preparation of the relatives of the child who will continue the treatment with antibiotics after discharge?

The interviews with the professionals were conducted by the primary author, in a private place, without the presence of other people and lasted approximately 20 minutes. To record the participants' speeches, they were recorded with the aid of digital media and later on transcribed. The entire data production process was guided and supervised by the secondary author, a researcher with extensive experience in qualitative research, with the primary author's proper training for the proper conduct of the interviews.

To guarantee anonymity, participants were identified with the word "Nur." referring to the Nurse professional category and the participants in the nursing technician professional category were identified with the phrase "Nur. tech.", followed by Arabic numerals respecting the order of their participation in the research, for example: Nur. 1, Nur. tech. 2, Nur. tech. 3, and so on.

The interviews were analyzed following the three phases of thematic analysis: ${ }^{9}$ a) pre-analysis; with floating reading for data organization and classification; b) exploration of the material, which consisted in the manual classification of the speech by color, with the colorimetric method, that is, the content was colored according to the participants' speeches and with repeated expressions; (c) result treatment and interpretation phase, in which data was aggregated into categories, generating the specificity of each theme.

In addition, categorization and analysis were done in pairs, initially by the primary and secondary authors. Subsequently, the material was subjected to critical analysis for the second pair, composed of the third and fourth authors.

The research followed the determinations proposed by Resolution 466/12 of the National Health Council, and was submitted to the Research Ethics Committee (REC) of the University Hospital located in the State of Rio de Janeiro, with the approval under opinion number 474.156 and CAAE 81164317.6.0000.5243. The participants in the research signed the Free and Informed Consent Term (FICT).

\section{RESULTS}

Fifteen nursing professionals were interviewed, 4 being nurses and 11 nursing technicians. Regarding age group, the professionals were between 20 and 50 years old. Regarding the time of activity in the pediatric sector, 7 were in the sector for up to 3 years; 4 from 3 to 5 years, and another 4 more than 10 years.

Four thematic units emerged from the thematic data analysis: Discharge preparation of relatives as a punctual moment; Professionals involved in preparing relatives for the discharge; Educational strategies in preparing relatives for the discharge; and Communication among professionals in preparing relatives for the discharge.

\section{Discharge preparation of relatives as a punctual moment}

Participants revealed that the preparation of relatives usually occurs at the time of hospital discharge when they are advised on how to prepare and administer the antibiotic at home:

Generally, preparation of antibiotic administration is done when the child is leaving (Nur. 10).

The person (relative) is prepared on the discharge day (Nur. 13).

Here we usually prepare them when they are about to be discharged, or 24 hours before, or even on the day of discharge we start to guide (Nur. 6).

At hospital discharge, the person is advised to go home and take an oral antibiotic (Nur. tech. 14).

In contrast, some professionals signaled that discharge preparation could be done during hospitalization, so that there would be more time for volume demonstrations and time adjustments, thus minimizing the risk for errors:

During hospitalization it would be better, because the mother would be more aware when doing it at home, so that she could not do it wrong. And to be able to demonstrate also the quantity, the correct times, because it has to be at the right times, it cannot exceed the time (Nur. tech. 8).

I see the need to prepare from the beginning of the hospitalization or as soon as possible [...] on the day of leaving, the person [family member] will have several doubts, because they never saw a syringe, never saw a medication like that, so it's a new thing for them (Nur. 10).

This guidance should be done with some prior notice. (...) Then we are already preparing that relative as for the administration of the medication and dose (Nur. 13).

\section{Professionals involved in preparing relatives for the discharge}

The interviewees had initially highlighted the doctor as the professional in charge for the guidance in relation to preparing the relatives for using the antibiotic at home. According to the speeches, the doctor verbally advises about the volume, time and drug storage:

We [nursing] do not enter [guide], but they [doctors] talk about the orientation, explain straight, how it should be administered, how it should be diluted (Nur. 1).

The doctor usually already gives the prescription, already gives guidance on how it will be given [the antibiotic], how many $\mathrm{ml}$, how many times a day (Nur. tech. 4). 
At child's discharge, the doctor advises how long they will have to take the antibiotic and the amount. The doctor is the one who prepares (Nur. tech. 9).

On the other hand, although not systematically, the professionals indicated that when relatives remain in doubt, after medical advices, they seek the nursing staff to remedy them. This, in turn, provides guidance on the prescription, drug administration times, using more understandable language, and demonstrations:

The doctors usually give this guidance, but sometimes the mother has doubts and resolves them with us [...] she comes with questions about the administration, the most frequently asked questions are what is written here [medical prescription]? What is the last time to continue doing the same time at home (Nur. Tech. 5).

Sometimes a relative comes to us, who does not understand what the doctor says, because the doctor says a lot, one thing on top of the other, that they [relatives] have their heads lost and come to us [nursing staff] and say that they did not understand what the doctor explained and that they know we report differently. Then we are orienting by the way we think they will understand, it is very funny, right?! (Nur. tech. 9)

Very often, the relative with more difficulty returns [after medical the advice] to the nursing staff with some doubt, and we do the things, show them how, so that when they get home they are able to do the things right (Nur. tech. 15).

It is a guidance set that starts up from the doctor. They (doctors) explain very well, then they (the relatives) continue with the doubt and the nursing staff also advises. (Nur. 6).

It was identified in the statements of nursing professionals that they feel more participative in the preparation of relatives when it comes to children with chronic diseases, such as diabetes, and who need continuous use drug:

When the child is a diabetic, we are already teaching because they have to leave us knowing how to do it, they and the guardians, they will not leave if they do not know, understood?! (Nur. 1)

Guidance exists when the patient is a diabetic, who discovered it a short time ago, we will teach how to do, how to administer, [...] we try to explain/guide before discharge and that is not this part of antibiotic (Nur. tech. 12).

\section{Educational strategies in preparing relatives for the discharge}

Regarding the educational practices developed in preparing relatives for the discharge for antibiotic administration for the child at home, verbal and written guidelines were cited, as well as demonstrations using a syringe and a measuring cup:

Just guidance, if there are doubts they will be guided as per the parent/guardian doubt. If the question is timerelated, we will explain and write the best times, we usually explain the time indicated here, when it is from $8 \mathrm{~h}$ to $8 \mathrm{~h}$, when it is from $6 \mathrm{~h}$ to $6 \mathrm{~h}$, the times we do (Nur. tech. 2).

To talk and, in the case of dosages, especially small ones, one should to show the amount on the syringe or even marked with the sticking plaster (Nur. tech. 4).

To guide on how to stir a syringe, to see the syringe graduation. [...] Because it is usually with a syringe that they [relatives] go home and will have to learn to handle all this, and then we teach the graduation, syringe numbering to mother, or to any relative who is with that child and then I ask them to do it also to see if they have understood (Nur. 10).

Usually we take the cup or syringe and show how we do to aspirate, dilute the drug and administer it taking care for the child not to choke. (Nur. 13).

The participants also signaled that the need for practical demonstration stems from the difficulty that some relatives have in understanding what is spoken and, thus, isolated verbal guidance is not sufficient. In this sense, demonstrative educational strategies are necessary, as well as supervision on the execution and removal of possible doubts that persist:

There has been a case where the mother doesn't understand anything from the conversation, we have to take a measuring cup and show it to the line [marking] that she will give at home, or we put a sticking plaster. Because it has to be like this, as she [mother] can't read anything, that's how we do it (Nur. 1).

We see that there are parents who have a lot of difficulty, so I think they deserve special attention from the doctor, really ask if there is any doubt, some time when a doubt comes up, refer it [to the nursing staff], ask us to show how to do the dilution (Nur. tech.2).

We guide verbally giving dosage of the syringe, in the syringe we show the dosage because sometimes they do not know or have no idea what is $1 \mathrm{ml}, 2 \mathrm{ml}$, understood!? So we sample in the syringe. We give guidance thus verbally and demonstrating (Nur. tech. 11). 
One professional added that she asks the relatives to tell her how they intend to administer the drug at home, so that she may identify their doubts and learning demands. In addition, she broadens her guidelines for child safety with accident prevention by requesting to leave the medicine out of reach.

At the time of hospital discharge, we ask the relative to say if they know how to administer and some people say they do not know how to read, so if necessary we even draw the sun and moon indicating that it is morning and evening. We also advise not to leave the drugs within the child's reach, because they may take the drug and use the wrong dose (Nur. tech. 7).

One professional indicated the importance related to using educational material, such as a booklet, that helps and facilitates the preparation of the relative for administering the antibiotic at home and that this instrument was made available to the same:

And they could have an instrument, such as a booklet, to make it easier for them [family member] to learn, and might give the booklet to them. Or I could do some little schematics for them to see better, some better scheme, so systematize what they are going to do at home. This would be the ideal that we do not see doing much in practice (Nur. 10).

\section{Communication among professionals in preparing relatives for the discharge}

The participants pointed out that the poor communication among the professionals of the medical and nursing staff results in flaws in the discharge planning process, so the guidelines are affected only when the child and the family leave the hospital. They also signaled that in daily care they are not informed about the children's therapy and drug treatment to be instituted at home. In addition, the drug is often prescribed orally on the day of discharge, with no possibility for monitoring the acceptance of the child before leaving the hospital:

This feedback from medicine and nursing usually does not happen. The doctor doesn't always tell us when the child will be discharged, we know from the parents. It is difficult for us to guide drug administration at home, but if this communication existed, maybe it would be feasible to do it. There has to be communication, without communication we have no way of knowing anything (Nur. tech. 5).

Often, we don't get to know what drug the patient that will be going home is going to use there, because the prescription does not pass through us (Nur. tech. 3).

There are children who, let's suppose, start up with a venous antibiotic and then one day before discharge, they pass to oral administration to see if they will accept it, because there are children who are very small and end up spitting! Then we teach the companion, we guide the mother, but it is very difficult that it happens... very difficult. Because she (doctor) usually changes the antibiotic on the day of discharge and passes to oral administration (at home) (Nur. 1).

We [nursing staff] are not aware of the continuity of the antibiotic [at home] we only provide guidance if the relative comes to us (Nur. tech. 12).

\section{DISCUSSION}

Regarding the discharge preparation of relatives as a punctual moment, the data from this research is in agreement with a study that highlighted that in the usual clinical practice in Brazil, the guidelines, including drug use, are performed at the time of hospital discharge and are limited to cursory and quick instructions without certifying that the patient has understood all the information. ${ }^{11}$ They are thus realized ineffectively, which may negatively impact autonomous, safe and quality home care. ${ }^{12}$

In this context, even without adequate discharge preparation, when the relative returns home, they resume the care of the child, including continuity of hospital-initiated drug treatment, and full decision-making responsibility without the direct support of health professionals. ${ }^{13}$ Thus, there is a need for an integrated action by the health team, including nursing, to ensure the safety of children using antibiotics at home.

The participants' perception on the need for the discharge process to be gradual is in accordance with the literature, as this should occur from the moment the patient is admitted to the institution and throughout the hospitalization period..$^{14}$

From this perspective, it is proposed that orientation sessions take place with information on the drugs to be used after discharge..$^{7,11}$ This process of continuing education allows more time for understanding the information, clarifying doubts and understanding the necessary guidelines for the cares. ${ }^{14}$

The speeches of the research participants regarding the role of the physician as the responsible person for the guidance in preparing relatives are in line with a study on the patient's discharge process. In the item of those who were discharged from the hospital, $44 \%$ of the patients appointed the doctor, $11 \%$ the medical student, $7 \%$ members of the nursing staff, and $35 \%$ were unaware on the role of their last advisor. ${ }^{15}$

It was found that the action of the nursing staff in orienting relatives happens only after the medical advice and when the family asks for it through doubts. Another study also pointed out that when the doctor discharges the patient, they orally guides, and the nurse or nursing technician delivers the prescription, guides again and clarifies the doubts. However, it is noted that there is no articulated action among health professionals in the discharge planning, so that the guidelines occur in an individualized and fragmented manner. ${ }^{16}$

Preparing discharge with a precise, clear and procedural guidance corroborates the prevention of adverse drug events that are aggravated by patient- and drug-related factors, lack or 
insufficient guidance on treatment, prescription of inappropriate drugs, non-adherence to treatment, and lack of therapeutic follow-up. ${ }^{17}$

The nursing staff pointed out that they feel involved in preparing the discharge when it comes to children who will be on continuous drug use, as in the case of insulin-dependent patients. These results are consistent with a study that addresses the experiences of nursing professionals in developing educational practices aimed at preparing the family to care for children who depend on technology or who have chronic disease, such as diabetes. ${ }^{18}$ In contrast, even drugs used for a few days, such as antibiotics, are at risk arising from misuse, such as bacterial resistance. ${ }^{19}$

In situations of care transition, such as hospital discharge, where the patient will be taken care of at home, he/she may be vulnerable to adverse events using the drugs. In the case of using antibiotics in children, all the necessary precautions should be taken as there may be increased levels of the drug in the body due to physiological factors of the child with consequent adverse effects. ${ }^{19}$

Within the community scope and at home, the literature points out that adverse events with drugs can interfere with the population's quality of life, causing discomfort and unease, as well as reducing adherence to treatment and trust in the health professionals. Thus, children's clinical condition may worsen, causing new adverse events, if they receive other drugs to reduce/alleviate the discomfort generated by the previously used drug, causing the so-called cascade effect. ${ }^{17}$

These risks are greater in case of misuse. In this sense, a Lebanese study identified among parents of children who used antibiotics at home that $20.6 \%$ did not follow medical instructions on the treatment dosage and duration; $64.3 \%$ terminated treatment early and diluted incorrectly. ${ }^{20}$

According to the participants' speeches, there is a need to develop, with the relatives, guidelines with an appropriate and easy to understand language, which facilitates care continuity at home. Some participating professionals reported that practical demonstrations enable the relative to develop skills in the correct handling of the syringe and aspiration of antibiotics for solutions. This type of approach is recognized as a safer promoter for the relative to administer the drug after hospital discharge from the perspective of the interviewed professionals.

These findings corroborate the literature that points out educational strategies used by the nurse in preparing relatives of children for home care, such as conversation circles with practical demonstrations of care to be performed at home. These strategies are well accepted by relatives because they feel that they are participative in the educational process. ${ }^{5,21}$

A study also indicates that the best resource for confirming that the guidance received has been understood is to ask the patient to repeat the instructions as they understood them or to demonstrate a newly learned technique ("Teach-back"). This is one of the most effective methods for improving patient's safety. ${ }^{11}$
One participant addressed the possible contribution of the existence of educational material as a resource for family guidance. Thus, the creation of teaching materials can assist in directing guidance by helping individuals to memorize the contents to be learned. ${ }^{14}$

A study at a university hospital in São Paulo revealed that after the discharge guidance conducted by the pharmacist, printed informational material with content on the drugs is provided, such as special care in the administration and storage, as well as personalized spreadsheets that facilitate the understanding of the dosage schedule. Providing educational material may be useful in combination with direct counseling or other behavioral interventions, but the use of printed guidelines or educational sessions alone does not improve patient compliance with the treatment. ${ }^{711}$

The nursing staff, as indicated by the participants, has no prior knowledge of the discharge of the patient or of their medication therapy at home. Corroborating these data, one study also highlighted failures in the communication among the health team members, definition of discharge on the same day and lack of multidisciplinary participation in daily patient visit. ${ }^{11}$ Ensuring effective communication can promote patient safety by permeating all interpersonal relationships. ${ }^{6}$

In addition, for discharge planning by the multidisciplinary team and the transition from patient to home, family participation should be valued in order to ensure continuity of care at home. Therefore, in order to provide better patient adherence and reducing hospital readmissions, it is necessary to orient, and to train techniques and care necessary for the patient's health. ${ }^{16}$

\section{FINAL CONSIDERATIONS}

In describing discharge preparation for relatives of hospitalized children for continuing antibiotic therapy at home, the study showed gaps related to this process, which should be continuous and not at the time of leaving hospital. In addition, failures in communication among the professionals are factors that negatively interfere with the development of educational actions and consequently the safety of child care at home.

The results point out to the need to systematize the discharge process of the child that leaves the hospital to complete the antibiotic treatment regimen at home, to avoid inappropriate use, with consequent failures in therapy and risks to the child's health. Improvements in the communication process are needed among professionals in the medical and nursing team, and among the professionals and their families.

In this regard, some strategies can be used, such as better communication in the team so that everyone may be aware of the discharge planning and of the home medication prescription, discharge preparation during hospitalization so that the relatives' educational demands may be met, use of educational resources such as demonstrations and written educational material. 
Regarding the limitation of the research, it is noteworthy that the relatives were not heard to make a counterpoint to the speeches of the professionals participating in the research, in addition to the reality depicted being from a pediatric hospital located in the state of Rio de Janeiro, so it is suggested to conduct new studies in other regions of the country to broaden the discussion and compare these results with others.

\section{REFERENCES}

1. Clark MA. Farmacologia ilustrada. $5^{\mathfrak{a}}$ ed. Porto Alegre: Artmed; 2013.

2. Magalhães TC, Ferrari CKB, David FL. Aspectos críticos da prescrição de medicamentos em pediatria. Evidência [Internet]. 2013; [citado 2017 mai 15]; 13(1):15-8. Disponível em: http://editora.unoesc.edu.br/index. php/evidencia/article/view/2755

3. Martins CF, Uberti MF, Warpechowski TP, Schuelter-Trevisol F, Trevisol DJ. Utilização de medicamentos em crianças internadas em um hospital geral. Sci Med [Internet]. 2017 mai; [citado 2018 set 24]; 27(2):1-9. Disponível em: http://revistaseletronicas.pucrs.br/ojs/ index.php/scientiamedica/article/view/25208/15657 DOI: https://doi. org/10.15448/1980-6108.2017.2.25208

4. Souza S, Rocha PK, Cabral PFA, Kusahara DM. Use of safety strategies to identify children for drug administration. Acta Paul Enferm [Internet]. 2014; [cited 2019 mai 21]; 27(1):6-11. Available from: http://www.scielo.br/scielo.php?script=sci_arttext\&pid=S010321002014000100003\&lng=en DOI: https://doi.org/10.1590/1982 0194201400003

5. Monnerat CP, Silva LF, Souza DK, Aguiar RCB, Cursino EG, Pacheco STA. Estratégia de educação em saúde com familiares de crianças em uso contínuo de medicamentos. Rev Enferm UFPE on line [Internet]. 2016; [citado 2017 jun 15]; 10(11):3814-22. Disponível em: http://www.revista.ufpe.br/revistaenfermagem/index.php/revista/ article/view/7640/pdf_1944 DOI: https://doi.org/10.5205/1981-8963v10i11a11461p3814-3822-2016

6. Wegner W, Silva MUM, Peres MA, Bandeira LE, Frantz E, Botene DZA, et al. Patient safety in the care of hospitalised children: evidence for paediatric nursing. Rev Gaúcha Enferm [Internet]. 2017; [cited 2019 mai 21]; 38(1):e68020. Available from: http://www.scielo.br/scielo. php?pid=S1983-14472017000100504\&script=sci_arttext\&tIng=en DOI: https://doi.org/10.1590/1983-1447.2017.01.68020

7. Lima BC, Silva LF, Góes FGB, Ribeiro MTS, Alves LL. The therapeutic pathway of families of children with cancer: difficulties faced in this journey. Rev Gaúcha Enferm [Internet]. 2018; [cited 2019 jun 21]; 39:e20180004. Available from: http://www.scielo.br/scielo. php?script=sci_arttext\&pid=S1983-14472018000100455\&lng=en DOI: https://doi.org/10.1590/1983-1447.2018.20180004

8. Marques LFG, Romano-Lieber NS. Estratégias para a segurança do paciente no processo de uso de medicamentos após alta hospitalar Physis [Internet]. 2014; [citado 2019 mai 21]; 24(2): 401-20. Disponível em: http://www.scielo.br/scielo.php?script=sci_arttext\&pid=S010373312014000200401\&lng=pt DOI: https://doi.org/10.1590/S010373312014000200005

9. Minayo MCS. O desafio do conhecimento: pesquisa qualitativa em saúde. 14를. ed. São Paulo: Hucitec; 2014.
10. Fontanella BJB, Magdaleno Junior R. Saturação teórica em pesquisas qualitativas: contribuições psicanalíticas. Psicol Estud [Internet].2012 mar [citado 2019 mai 20]; 17(1):63-71. Disponível em: http://www.scielo.br/scielo.php?script=sci_arttext\&pid=S1413-73722012000100008\&lng=en\&nr m=iso\&tlng=pt DOl:https://doi.org/10.1590/S1413-73722012000100008

11. Marques LFG, Romano-Lieber NS. Segurança do paciente no uso de medicamentos após a alta hospitalar: estudo exploratório. Saude Soc [Internet]. 2014 dez; [citado 2017 jul 30];23(4):1431-44. Available from: http://www.scielo.br/scielo.php?script=sci_arttext\&pid=S0104-12902014000401431\&ln $\mathrm{g}=$ en\&nrm=iso DOI: https://doi.org/10.1590/S0104-12902014000400025

12. Meyers AG, Salanitro A, Wallston KA, Cawthon C, Vasilevskis EE, Goggins KM, et al. Determinants of health after hospital discharge rationale and design of the Vanderbilt Inpatient Cohort Study (VICS) BMC Health Serv Res [Internet]. 2014 jan; 14:10. Available from: https:// doi.org/10.1186/1472-6963-14-10

13. Pinto JP, Mandetta MA, Ribeiro CA. The family living the child recovery process after hospital discharge. Rev Bras Enferm [Internet]. 2015 aug; [cited 2019 mai 21]; 68(4):594-602. Disponível em: http://www. scielo.br/scielo. php? pid=S0034-71672015000400594\&script=sci arttext\&tIng=en DOI: https://doi.org/10.1590/0034-7167.2015680404i

14. Souza PMBB, Queluci GC. Considerações sobre os cuidados de enfermagem aos pacientes na alta hospitalar: revisão integrativa. Rev Enferm UFPE on line [Internet]. 2013 out; 7(esp):6238-44. DOI: https:// doi.org/10.5205/1981-8963-v7i10a12262p6238-6244-2013

15. Alóchio KV, Cruz ICF. A segurança do paciente na preparação de sua alta na UTI: revisão sistematizada da literatura para um protocolo clínico. JSNCare [Internet]. 2016 jun; [citado 2017 mai 12]; 8(1). Disponível em http://www.jsncare.uff.br/index.php/jsncare/article/view/2804/679

16. Fontana G, Chesani FH, Menezes M. As significações dos profissionais da saúde sobre o processo de alta hospitalar. Sau Transf Soc [Internet] 2017 mai/ago; [citado 2017 jul 30]; 8(2):86-095. Disponível em: http:// www.redalyc.org/articulo.oa?id=265352024010

17. Sousa LAO, Fonteles MMF, Monteiro MP, Mengue SS, Bertoldi AD, Pizzol TSD, et al. Prevalência e características dos eventos adversos a medicamentos no Brasil. Cad Saúde Pública [Internet].2018; [citado 2019 mai 22]; 34(4):e00040017. Disponível em: http://www.scielo.br/scielo. php?script=sci_arttext\&pid=S0102-311X2018000405005\&lng=pt DOI https://doi.org/10.1590/0102-311x00040017

18. Azevedo AVS, Lançoni Júnior AC, Crepaldi MA. Interação equipe de enfermagem, família, e criança hospitalizada: revisão integrativa. Ciênc Saúde Coletiva [Internet]. 2017; [citado 2017 mai 08]; 22(11):3653-66. Disponível em: http://www.scielo.br/scielo.php?script=sci_arttext\&p id=S1413-81232017021103653 DOI: https://doi.org/10.1590/1413812320172211.26362015

19. Paganotti AM, Reis RA, Crozatti MTL, Silva ATA, Fegadolli C. Prescrição de antibióticos a crianças atendidas no inverno em Unidade de Saúde de município paulista. Rev Ciênc Farm Básica Apl [Internet]. 2013 [citado 2018 jun 01]; 34(3):441-7. Disponível em: https://lume.ufrgs.br/ handle/10183/86864

20. Hallit S, Zahreddine L, Saleh N, Shakaroun S, Lahoud N. Practice of parents and pharmacists regarding antibiotics use in pediatrics: A 2017 cross-sectional study in Lebanese community pharmacies. J Eval Clin Pract. 2019 may; 1-9. Available from: https://doi.org/10.1111/jep.13165

21. Viana IS, Silva LF, Cursino EG, Conceição DS, Goes FGB, Moraes JRMM. Educational encounter of nursing and the relatives of children with special health care needs. Texto Contexto - Enferm [Internet]. 2018; [cited 2019 mai 21];27(3):e5720016. Disponível em:http://www.scielo.br/ scielo.php?script=sci_arttext\&pid=S0104-07072018000300316\&lng=pt DOI: https://doi.org/10.1590/0104-070720180005720016

\footnotetext{
${ }^{a}$ Article extracted from the Final Study of the Undergraduate Course referred to as "The nursing staff in preparing relatives for hospital discharge of the child on antibiotics", authored by Luciana Lima Alves, under the guidance of Liliane Faria da Silva; submitted to Núcleo de Pesquisa e Estudos em Saúde Integral da Criança e Adolescente (NUPESICA) of the Aurora de Afonso Costa Nursing School of Universidade Federal Fluminense, in the 1st semester of 2018.
} 